\title{
Liver Enzymes and Non-Alcoholic Fatty Liver Disease: Important Factors in Assessing Patterns of Clinical Management in Type-2 Diabetes Patients [Letter]
}

\author{
Abdul Moeed (1D \\ Department of Internal Medicine, Dow University of Health Sciences, Karachi, Pakistan \\ Correspondence: Abdul Moeed, Department of Internal Medicine, Dow University of Health Sciences, Karachi, Pakistan, Tel +92 306I I59372, \\ Email abdulmoeedII7@outlook.com
}

\section{Dear editor}

Recently, an original study titled "Statin Prescription Patterns and Associated Factors Among Patients with Type 2 Diabetes Mellitus Attending Diabetic Clinic at Muhimbili National Hospital, Dar es Salaam, Tanzania"1 was published by Aneth Telesphore Bideberi et al in the reputable journal "Diabetes, Metabolic Syndrome and Obesity: Targets and Therapy". Firstly, I would like to congratulate the authors and acknowledge their successful publication.

This hospital-based cross-sectional study, conducted in an outpatient setting, discussed the patterns and predictors correlated with statins prescription among type 2 diabetes mellitus (T2DM) patients. This study further stratified patients according to the risk of cardiovascular disease. Although this study was successful in identifying age, medical insurance, and hypertension as potential factors of statin prescription, I feel the study fails to identify aspartate aminotransferase (AST) and alanine aminotransferase (ALT), which have been significantly associated with cardiovascular diseases (CVD) in T2DM patients. Furthermore, this study provides an incomplete understanding of the patient demographics as nonalcoholic fatty liver disease (NAFLD) is not included, which remains vital in prescribing statins.

Multiple studies have proven AST and AST-to-ALT ratio as a predictor of CVD. Although AST is released from multiple tissues, including the myocardium and the liver, ALT is only liver-dependent. Thus, increased AST-to-ALT ratio indicates $\mathrm{CVD}^{2}$ through various potential mechanisms, including increased insulin resistance, chemical mediators of inflammation, and oxidative stress. ${ }^{3}$ Lazo et al significantly correlated elevated AST and ALT levels with cardiac biomarkers; troponin T and NT-proBNP. ${ }^{4}$ Hence, cementing the role of AST and ALT in subclinical myocardial injury. Thus, to identify patterns in statins prescriptions for prevention of CVD, it is pertinent to include AST and ALT levels in the patient profile as they are crucial markers in T2DM patients at risk of CVD.

Moreover, NAFLD has been increasingly associated with T2DM; as much as $70-80 \%$ of T2DM patients have NAFLD. ${ }^{5}$ Thus, it is essential to identify and diagnose NAFLD in T2DM patients to formulate an efficacious treatment plan. As NAFLD is correlated with increased prevalence of CVD (coronary, cerebrovascular, and peripheral vascular disease), [5] its diagnosis is paramount in the prescription of statins to better the prognosis in T2DM patients.

It is evident from the above-mentioned articles that to formulate a treatment plan and assess the prescription patterns of statins in T2DM patients at risk of CVD, the inclusion of NAFLD and transaminases levels is of immense importance. Further large-scale studies must be conducted with a well-formulated methodology to understand this association better.

\section{Disclosure}

The author reports no conflicts of interest for this communication. 


\section{References}

1. Bideberi AT, Mutagaywa R. Statin prescription patterns and associated factors among patients with Type 2 diabetes mellitus attending diabetic clinic at Muhimbili National Hospital, Dar Es Salaam, Tanzania. Diabetes, Metab Syndr Obes Targets Ther. 2022;15:633-646. doi:10.2147/DMSO. S347765

2. Glinghammar B, Rafter I, Lindström AK, et al. Detection of the mitochondrial and catalytically active alanine aminotransferase in human tissues and plasma. Int J Mol Med. 2009;23(5):621-631. doi:10.3892/ijmm_00000173

3. Targher G, Bertolini L, Rodella S, et al. NASH predicts plasma inflammatory biomarkers independently of visceral fat in men. Obesity. 2008;16 (6):1394-1399. doi:10.1038/oby.2008.64

4. Lazo M, Rubin J, Clark JM, et al. The association of liver enzymes with biomarkers of subclinical myocardial damage and structural heart disease. $J$ Hepatol. 2015;62(4):841-847. doi:10.1016/j.jhep.2014.11.024

5. Targher G, Bertolini L, Padovani R, et al. Prevalence of nonalcoholic fatty liver disease and its association with cardiovascular disease among type 2 diabetic patients. Diabetes Care. 2007;30(5):1212-1218. doi:10.2337/dc06-2247

Dove Medical Press encourages responsible, free and frank academic debate. The content of the Diabetes, Metabolic Syndrome and Obesity: Targets and Therapy 'letters to the editor' section does not necessarily represent the views of Dove Medical Press, its officers, agents, employees, related entities or the Diabetes, Metabolic Syndrome and Obesity: Targets and Therapy editors. While all reasonable steps have been taken to confirm the content of each letter, Dove Medical Press accepts no liability in respect of the content of any letter, nor is it responsible for the content and accuracy of any letter to the editor.

Diabetes, Metabolic Syndrome and Obesity: Targets and Therapy

\section{Publish your work in this journal}

Diabetes, Metabolic Syndrome and Obesity: Targets and Therapy is an international, peer-reviewed open-access journal committed to the rapid publication of the latest laboratory and clinical findings in the fields of diabetes, metabolic syndrome and obesity research. Original research, review, case reports, hypothesis formation, expert opinion and commentaries are all considered for publication. The manuscript management system is completely online and includes a very quick and fair peer-review system, which is all easy to use. Visit http://www.dovepress. com/testimonials.php to read real quotes from published authors.

Submit your manuscript here: https://www.dovepress.com/diabetes-metabolic-syndrome-and-obesity-targets-and-therapy-journal 